\title{
DENSITAS DAN AKTIVITAS AYAM HUTAN MERAH (Gallus gallus) DI HUTAN GUNUNG KLABAT, MINAHASA UTARA, SULAWESI UTARA
}

\author{
Marton Puasa $^{1)}$, Saroyo ${ }^{1)}$, Lalu Wahyudi ${ }^{1)}$ \\ ${ }^{1)}$ Program Studi Biologi FMIPA UNSRAT Manado, 95115
}

\begin{abstract}
Red jungle fowl is one of the important animals that live in the forest and has various roles, such as ecological, economic and aesthetic functions. This study aims to analyze the population of red jungle fowl in forest habitat I and forest habitat II in the forest of Mount Klabat Utara Minahasa and analyze the activity of red forest chicken in forest habitat I and forest habitat II in the forests of Mount Klabat North Minahasa. This study uses a survey method with line transect sampling. Transects were determined as many as four, namely two transects in forest habitat type I and two transects in forest habitat type II. Each transect length is $2000 \mathrm{~m}$ and the left width is $20 \mathrm{~m}$ and the right width is $20 \mathrm{~m}$, each transect is observed for 10 times. Density found in transect I was 25.63 animals $/ \mathrm{km}^{2}$ and transect II was 10.63 animals $/ \mathrm{km}^{2}$, in addition it was found that the dominant activity in both types of forest was forest I with feeding activity 19 (0.76\%) moved $4(0.16 \%)$, rest $2(0.20 \%)$, in forest II looking for food, $5(0.50 \%)$, move 3 $(0.30 \%)$, rest $2(0.20 \%)$.
\end{abstract}

Keywords: Red jungle fowl (Gallus gallus), density, activity, Mount Klabat, North Minahasa, North Sulawesi

\begin{abstract}
ABSTRAK
Ayam hutan merah merupakan salah satu satwa penting yang hidup di hutan dan mempunyai berbagai peran, seperti fungsi ekologi, ekonomi dan estetika. Penelitian ini bertujuan menganalisis populasi ayam hutan merah pada habitat hutan I dan habitat hutan II di hutan Gunung Klabat Minahasa Utara dan menganalisis aktivitas ayam hutan merah pada habitat hutan I dan habitat hutan II di hutan Gunung Klabat Minahasa Utara. Penelitian ini menggunakan metode survei dengan sampling berbentuk transek garis. Transek ditentukan sebanyak empat, yaitu dua transek pada tipe habitat hutan I dan dua transek pada tipe habitat hutan II. Panjang transek masing-masing ialah $2000 \mathrm{~m}$ dan lebar kiri $20 \mathrm{~m}$ dan lebar kanan 20m, setiap transek dilakukan pengamatan selama 10 kali. Densitas yang di temukan pada transek I yaitu 25.63 ekor $/ \mathrm{km}^{2}$ dan di transek II $10.63 \mathrm{ekor} / \mathrm{km}^{2}$, selain itu di temukan aktivitas yang dominan pada kedua tipe hutan yaitu hutan I dengan aktivitas makan $19(0.76 \%)$ berpindah $4(0.16 \%)$, istirahat 2 $(0.20 \%)$, di hutan II mencari makan, $5(0.50 \%)$, berpindah $3(0.30 \%)$, istirahat 2 $(0.20 \%)$.
\end{abstract}

Kata kunci: Ayam hutan merah (Gallus gallus), densitas, aktivitas, Gunung Klabat, Minahasa Utara, Sulawesi Utara 


\section{PENDAHULUAN}

Ayam hutan merah merupakan salah satu satwa penting yang hidup di hutan dan mempunyai berbagai peran, seperti fungsi ekologi, ekonomi dan estetika. Di alam, ayam hutan merah sebagai mangsa bagi hewan predator, sebagai hewan buru, sumber genetik, hewan piaraan, dan sebagai hewan hias (Al-Nasser et al., 2007; Collias et al., 1991).

Salah satu lokasi di Pulau Sulawesi yang menjadi habitat ayam hutan merah ialah Gunung Klabat di Kabupaten Minahasa Utara Pada tahun 2015 terjadi kebakaran besar di Gunung Klabat sampai mencapai puncak yang dapat berpengaruh terhadap habitat dan populasi satwaliar termasuk ayam hutan merah. Umumnya,

Penelitian ini penting dilakukan untuk mengetahui densitas dan aktivitas ayam hutan merah di hutan Gunung Klabat. Penetuannya menggunakan garis transek (Line transeck).

\section{METODOLOGI PENELITIAN}

\section{Waktu dan Tempat Penelitian}

Penelitian dilakukan pada bulan Febuari 2018 sampai Agustus 2018. Lokasi penelitian adalah hutan Gunung Klabat, Kabupaten Minahasa Utara Provinsi Sulawesi Utara. Lokasi penelitian terletak pada ketinggian 700$800 \mathrm{~m}$ dpl. Untuk menghitung densitas ayam hutan merah pada setiap transek digunakan persamaan menurut (Mickhael, 1986). Metode yang digunakan dalam menghitung densitas ayam hutan merah yaitu metode line transek (Buckland et al., 1993)

\section{Peralatan Penelitian}

Binokuler, GPS, alat tulis menulis, kamera, dan meteran.

\section{Penentuan Lokasi}

Lokasi penelitian dilakukan di Hutan Gunung Klabat, Minahasa Utara, Sulawesi Utara.

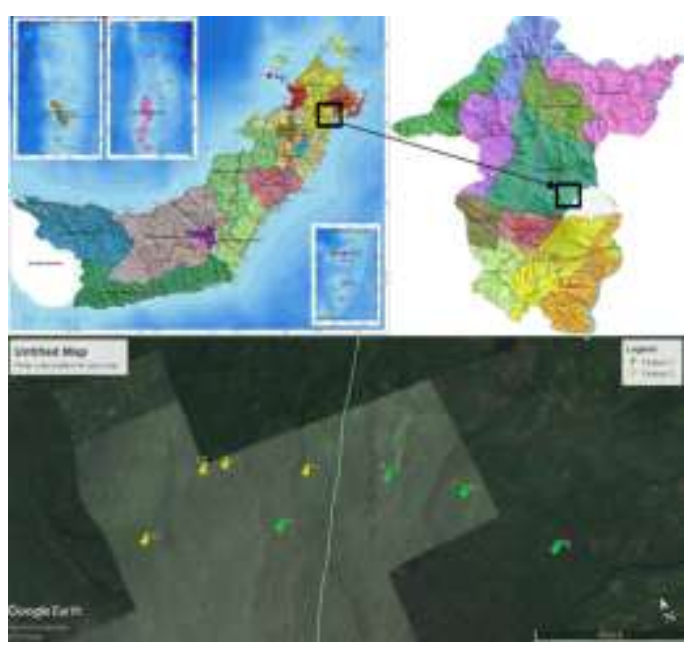

Gambar 1. Peta Lokasi Penelitian

\section{Metode Penelitian}

Dalam penelitian ini digunakan metode survei dengan sampling berbentuk transek garis untuk menentukan kepadatan populasi (densitas) ayam hutan merah (Buckland et al., 1993). Transek ditentukan sebanyak empat, yaitu dua transek pada tipe habitat hutan I dan dua transek pada tipe habitat hutan II. Panjang transek masing-masing ialah $2000 \mathrm{~m}$ dan lebar kiri $20 \mathrm{~m}$ dan lebar kanan $20 \mathrm{~m}$.

\section{Metode pengambilan data}

Pengambilan data dilakukan setiap pagi hari dari jam 05.30-07.00 pagi dan dilanjutkan pada jam 17.0018.00 sore. Keempat transek pada garis tersebut (Tabel 1). Setiap transek dilakukan pengamatan selama 10 kali. 


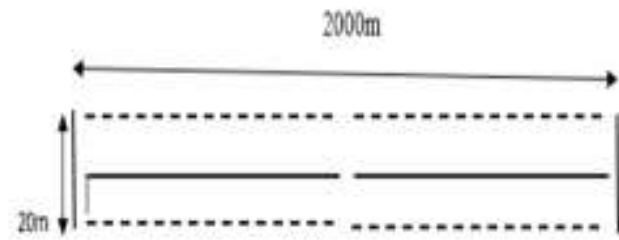

Gambar 2. Garis transek

\section{Analisis Data}

Data yang dikumpulkan
dianalisis untuk menentukan
densitas/kepadatan populasi. Untuk
menghitung densitas ayam hutan merah
pada setiap transek digunakan
persamaan menurut (Mickhael, 1986)
sebagai berikut:
Untuk menghitung densitas
ayam hutan merah digunakan
persamaan sebagai berikut:

Densitas $=($ Lindivu $) /($ Luas area $)$

Untuk menghitung luas transek menggunakan persamaan:

$\mathrm{L}=$ panjang transek $\mathrm{x}$ lebar transek

\section{HASIL DAN PEMBAHASAN}

Gunung Klabat di bagian selatan berbatasan dengan Kecamatan Airmadidi, sebelah barat berbatasan dengan Kecamatan Dimembe, sebelah timur berbatasan dengan Kecamatan Watudambo, sebelah utara berbatasan dengan Kecamatan Dimembe. Lokasi penilitian berada di sebelah atas Desa Penilih Kecamatan Dimembe dan Desa Klabat Kecamatan Dimembe.

Survei dalam penelitian ini dilakukan pada dua tipe habitat, yaitu habitat hutan I dan habitat hutan II. Hutan I merupakan hutan yang masih alami, yang masih utuh dan belum mengalami gangguan eksploitasi oleh manusia. Hutan II merupakan hutan yang tumbuh berkembang secara alami sesudah terjadi kerusakan/perubahan pada hutan yang pertama (Lamprecht, 1986).

\section{Hutan I}

Lokasi penelitian pada habitat hutan I berada pada ketinggian 782-848 m dpl. Lokasi ini berupa lereng Gunung Klabat dengan kemiringan hingga \pm $60^{\circ}$. Tajuk hutan I ini sering terlihat oleh tumbuhan tingkat pohon seperti dari genus Ficus, Canarium sp yang cukup mendukung kondisi lokasi tersebut. Selain itu juga daerah hutan ini masih alami atau belum ada perubahan akibat dari aktivitas manusia. Habitat yang masih alami juga ditandai dengan terjadi tumbuhan tingkat semai dan jenis paku-pakuan.

Hutan di Gunung Klabat sebagaimana hutan-hutan di wilayah hujan tropis merupakan habitat ideal bagi satwa termasuk ayam hutan. Hutan hujan tropis ditumbuhi beragam jenis pohon yang membentuk lapisan tajuk. Secara umum terdapat pohon bertajuk tinggi yang membentuk kanopi menaungi tanaman lainnya, kemudian pohon menengah seperti tanaman merambat dan perdu dan terakhir tanaman permukaan tanah seperti rumput dan lumut.

\section{Hutan II}

Hutan II berada ketinggian sekitar 714-740 m dpl, didominasi oleh tumbuhan tingkat semai yang relatif pendek. Hutan ini menempati kaki Gunung Klabat yang dominan sudah menjadi peralihan fungsi hutan. 
Dibeberapa tempat dijumpai tumbuhan alang-alang (Imperata cylindrica) yang menunjukkan adanya suksesi hutan. Suksesi ini berhubungan dengan terjadinya kebakaran hutan Gunung Klabat pada tahun 2014.

Perubahan pada salah satu komponen tersebut akan mempengaruhi keseluruhan sistem kehidupan yang ada di dalamnya. (Fachrul, 20017). Lokasi hutan II ini menempati kaki Gunung Klabat yang sudah mengalami perubahan akibat aktivitas manusia sehingga dapat dijumpai adanya kebun kelapa, cengkih, dan perladangan. Seperti dapat dilihat pada (Gambar 4). Selain itu juga terdapat beberapa tumbuhan yang ditemukan di habitat hutan II di antaranya Trema orientalis, genus Aglaia, Cananga odorata, genus Polyalthia, Podocarpus imbricatus, Albizia saponaria, Cocos Nucivera dan Garcinia sp.

\section{Densitas Ayam hutan Merah}

Hasil pengamatan pada kedua tipe habitat ditemukan ayam hutan merah dengan jumlah dan kepadatan seperti disajikan pada Tabel. Hasil perhitungan densitas juga menunjukkan bahwa densitas dihutan I lebih tinggi dari hutan II hal ini menunjukkan bahwa habitat yang ada dihutan I tergolong habitat yang masih alami.
Tabel. Densitas ayam hutan merah

\begin{tabular}{llccc}
\hline Habitat & Transek & Ekor & $\begin{array}{c}\text { Densitas } \\
\left(\mathrm{ekor} / \mathrm{km}^{2}\right)\end{array}$ & $\begin{array}{c}\text { Rata- } \\
\text { rata }\end{array}$ \\
\hline Hutan & Hutan I (a) & 14 & 17.5 & \\
I & Hutan I (b) & 13 & 16.25 & 25.63 \\
& & & & \\
Hutan & Hutan II (a) & 5 & 6.25 & 10.63 \\
II & & \multicolumn{2}{c}{7,5} & \\
& Hutan II (b) & 6 & &
\end{tabular}

Hasil penelitian oleh Wantania Fanny (2010) dengan lokasi penelitian yang sama yaitu di hutan Gunung Klabat, memiliki densitas yaitu 25 ekor $/ \mathrm{km}^{2}$ di habitat hutan I dan habitat huatan II. Dengan hasil penelitian ini dapat dikatakan bahwa densitas ayam hutan merah di hutan Gunung Klabat mengalami penurunan jumlah individu yang ada di tipe habitat hutan II Gunung Klabat.

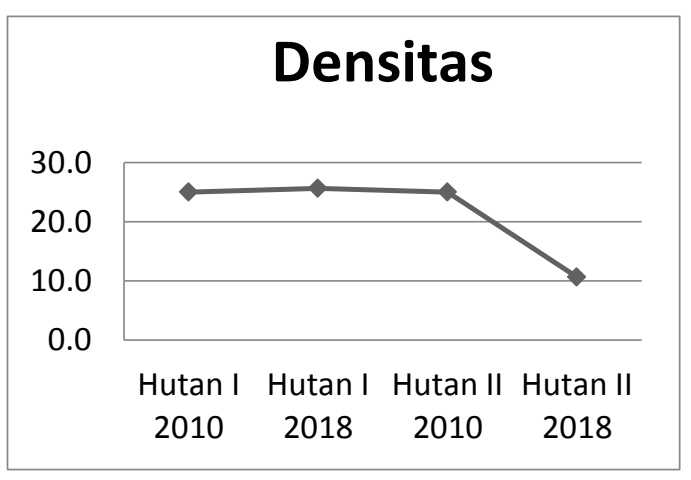

Gambar. 2 Grafik perbandingan densitas

Hutan I mengalami penambahan jumlah individu ayam hutan merah dari penelitian sebelumnya. Hal ini disebabkan karena habitat pada lokasi ini lebih sesuai untuk kehidupan ayam hutan merah. Beberapa faktor yang mendukung kehidupan spesies ini antara lain vegetasi yang lebat, pakan 
yang melimpah, dan aktivitas manusia lebih rendah dibandingkan dengan kawasan hutan II.

Peningkatan densitas pada tahun 2018 dibandingkan dengan 2010 pada habitat hutan I tersebut disebabkan oleh adanya perbaikan dan peningkatan pengawasan di areal hutan lindung pasca kebakaran hutan pada tahun 2014. Naiknya jumlah densitas burung diakibatkan dari jenis pakan yang tersedia dan habitat yang mendukung individu untuk berkembang biak (Mangangantung, et all., 2015).

Hutan II mengalami penurunan jumlah individu ayam hutan merah di bandingkan dengan tahun sebelumnya. Penyebab utama menurunnya jumlah individu dalam suatu kawasan yaitu gangguan dari aktivitas manusia dalam hal ini perburuan liar, penebangan hutan, alih fungsi lahan dan aktivitas lainnya sehingga dapat menggangu keberadaan ayam hutan merah pada suatu habitat.

Salah satu aktivitas yaitu perburuan yang tidak terkendali dan dimangsa predator diperkirakan sebagai penyebab penurunan populasi ayam hutan merah yang mengarah pada kepunahan (Setianto et al., 2016). Selain itu, penangkapan yang tidak terkendali yang dilakukan terus menerus dapat menyebabkan kepunahan. Perburuan terhadap ayam hutan merah terus berlangsung dengan berbagai macam dari cara tradisional sampai penggunaan peralatan modern. (Akrim et al., 2015). Untuk itu upaya pelestarian perlu dilakukan agar keberadaan akan terjaga (Setianto et al., 2015).
Angka densitas yang didapat pada ke dua tipe lokasi habitat tersebut yaitu 10, 63 ekor/ $\mathrm{km}^{2}$ untuk hutan II dan 25,63 ekor $/ \mathrm{km}^{2}$ di hutan I. Densitas tersebut dapat ditingkatkan apabila dilakukan perbaikan tata kelola hutan lindung Gunung Klabat mengingat berbagai gangguan dan ancaman masih terjadi.

Kemudian dalam pengamatan ayam hutan merah di kawasan hutan Gunung Klabat sangat sering dijumpai individunya hal ini karena speiesnya yang menurun dan juga tergolong dalam satwa yang perilakunya sangat sensitif terhadap suara atau pergerakan yang mencurigakan. Faktor lain yaitu, kondisi lokasi yang terdapat banyak juram sehingga sulit untuk menemukan spesiesnya. Untuk menghindari predator, individu tersebut akan berpindah dengan cara lari atau terbang menjauh lari dari tempat asalnya, langkah ini dilakukan karena merasa terancam (Dewantara et al., 2015). Menghindar adalah bentuk dari strategi pertahanan untuk menghindari diri dari pemangsa dan gangguan lainnya (Alikodra, 1990).

\section{Aktivitas Ayam Hutan Merah}

Penelitian dilakukan pada dua tipe habitat yaitu habitat hutan I dan habitat hutan II dimana selain jumlah individu, tetapi sekaligus termasuk aktivitas sesaat individu tersebut terdata. Ayam hutan merah yang paling banyak ditemukan selama penelitian adalah ayam dewasa di kedua tipe habitat tersebut. Tabel dibawah ini merupakan data penelitian di kedua tipe hutan tersebut yang mana selain data 
idividu tetapi juga data aktivitas sesaat perjumpaan dengan objek ayam hutan. Ayam hutan yang dijumpai seluruhnya adalah ayam hutan dewasa dan terdata pada berbagai aktivitas sesaat seperti mencari makan (feeding), berpindah (moving) dan istirahat (Resting) .

Tabel 1. Aktivitas ayam hutan merah

\begin{tabular}{lccc}
\hline \multicolumn{1}{c}{ Aktivitas } & \multicolumn{1}{c}{ Hutan II } & Jumlah \\
\hline & A & B & \\
\hline Mencari makan & 3 & 2 & $5(0.50 \%)$ \\
Berpindah & 0 & 3 & $3(0.30 \%)$ \\
Istirahat & 2 & 0 & $2(0.20 \%)$ \\
Jumlah $(\%)$ & $5(0.50 \%)$ & $5(0.50 \%)$ & $10(100 \%)$ \\
\hline
\end{tabular}

Tabel 2. Aktivitas ayam hutan merah

\begin{tabular}{|c|c|c|c|}
\hline \multirow{2}{*}{ Aktivitas } & \multicolumn{2}{|c|}{ Hutan I } & \multirow[t]{2}{*}{ Jumlah } \\
\hline & A & $\mathrm{b}$ & \\
\hline $\begin{array}{l}\text { Mencari } \\
\text { makan }\end{array}$ & 10 & 9 & $19(0.76 \%)$ \\
\hline Berpindah & 1 & 3 & $4(0.16 \%)$ \\
\hline Istirahat & 2 & 0 & $2(0.20 \%)$ \\
\hline Jumlah (\%) & $\begin{array}{l}13 \\
(0.52 \%)\end{array}$ & $\begin{array}{l}12 \\
(0.48 \%)\end{array}$ & $25(100 \%)$ \\
\hline
\end{tabular}

Pada hasil persentasi aktivitas ayam hutan merah pada kedua tipe habitat hutan Gunung Klabat dengan transek yang sama, dapat dijelaskan bahwa, aktivitas mencari makan $0.76 \%$, berpindah $0.16 \%$, istirahat $0.20 \%$ yang ada di hutan I. Sedangkan di hutan II dengan aktivitas mencari makan $0.50 \%$, berpindah $0.30 \%$, dan istirahat $0.20 \%$, di hutan II dengan demikian aktivitas makan yang tercatat paling besar proporsinya dibanding aktivitas lainnya.

Aktivitas makan mendominasi dari keseluruhan aktivitas dapat dijelaskan bahwa, sebagian besar aktivitas ayam hutan merah pada siang hari yaitu mencari makan untuk memenuhi kebutuhan nutrisinya. Arshad (1999) menyatakan bahwa tingkah laku alami ayam hutan umumnya pada pagi hari setelah meninggalkan rumah/sarang di atas pohon akan langsung mencari makanan. Ayam hutan jantan cenderung mengais lubang yang besar dan dalam untuk mendapatkan makanan untuk menunjukan perhatiannya kepada ayam betina.

\section{KESIMPULAN}

Berdasarkan hasil penelitian dan pembahasan dapat disimpulkan:

1. Densitas ayam hutan merah (Gallus gallus) di habitat hutan I ialah 25.63 ekor $/ \mathrm{km}^{2}$ sedangkan di habiatat hutan II $10.63 \mathrm{ekor} / \mathrm{km}^{2}$.

2. Aktivitas ayam hutan merah (Gallus gallus) pada kedua kawasan hutan diantaranya, di haitat hutan I mencari makan $19(0.76 \%)$, berpindah 4 $(0.16 \%)$, istirahat $2(0.20)$ dan di habitat hutan II mencari makan 5 (0.50\%), berpindah $3 \quad(0.30 \%)$ istirahat $2(0.20)$.

\section{SARAN}

Diperlukan perhatian khusus dari pemerintah Kehutanan untuk lebih memperhatikan kawasan hutan Gunung Klabat sehingga meminimalisasi penebangan hutan yang terus menerus, karena salah satu hutan lindung dan tempat bagi spesies yang hidup di dalamnya salah satunya ayam hutan merah (Gallus-gallus). 
DAFTAR PUSTAKA

Akrim, F, Awan MS, Mahmood T et al. 2015. Threats to red jungle fowl (Gallus gallus murghi) in Deva Vatala National Park, District Bhimber, Azad Jammu and Kashmir, Pakistan. Annu Res Rev Biol 6 (1): 59-65

Al-Nasser.A. Al-Khalaifa. H. and AlSaffar. A. 2007. Overview of chicken taxonomy and domestication. World's Poult Sci J 63: 285300.

Alikodra, H.S. 1990. Pengelolaan Satwa Liar. Departemen Pendidikan dan Kebudayaan, Direktorat Jenderal Pendidikan Tinggi, Pusat Antar Universitas Ilmu Hayati. Institut Pertanian Bogor. Bogor.

Arshad, M. I. 1999. An ecological study of red jungle fowl (gallus gallus spadiceus) in agriculture areas. Dissertation. UPM, Malaysia. Of complete diet, corn and soybean. Bulletin of aniamal scince. Suppl. Edition. Pp. 482485.

Setianto, J., H. Prakoso, Sutriyono. 2015a. Domestikasi ayam hutan merah: Studi kasus penangkapan ayam hutan merah oleh masyarakat di Bengkulu Utara. Prosiding Seminar Nasional Masyarakat Biodiversitas Indonesia. 1(2): 207212.

Setianto, J., Zain, B, Prakoso H, Sutriyono. 2016a. Domestikasi ayam hutan merah: Studi kasus pengadaan bibit oleh masyarakat di Bengkulu Tengah. Seminar Nasional Masyarakat Biodiversitas Indonesia. Bogor 17 September 2016
Buckland, S.T. Anderson, D. R., Burnham, K. Mangangantung, B. Deidy. Y. Katili. Saroyo. Pience. V. Maabuat. 2015. Densitas dan Jenis Pakan Burung Rangkong (Rhyticeros cassidix) di Cagar Alam Tangkoko Batuangus. Jurnal MIPA UNSRAT ONLINE 4 (1) 88-92.

Fanny, W. 2010. Analisis Keragaman Burung Di Gunung Klabat. Sulawesi Utara. [Skripsi]. Manado 7 Juni 2010.

Grzimek,s HCB. 1972 . Animal Encyclopedia, 8; Bird II Van Nostrand Rein Hold co, New York. p 49.

Handiwirawan, E. 2004. Pelestarian ayam hutan melalui pembentukan ayam bekisar untuk ternak kesayangan. Prosiding Lokakarya Nasional Inovasi Teknologi Pengembangan Ayam Lokal. Semarang.

Lamprecht H. 1989. Silvikulture in the Tropics. Deutsche Gesselschaft für Technische Zusammenarbeit (GTZ) GmbH. Eschborn. Germany.

Michael, P. 1986. Ecological Methods for Field and Laboratory Investigations. Tata McGrawHill Publishing Company. New Delhi.

Mangangantung, B. Deidy. Y. Katili. Saroyo. Pience. V. Maabuat. 2015. Densitas dan Jenis Pakan Burung Rangkong (Rhyticeros cassidix) di Cagar Alam Tangkoko Batuangus. Jurnal Mipa Unsrat Online 4 (1) 88-92. 